\title{
Perceived Compensation Fairness, Job Design, and Employee Motivation: The Mediating Role of Working Environment
}

\author{
Muhammad Imran Rasheed * $\quad$ Warda Najeeb Jamad ${ }^{\dagger} \quad$ Abdul Hameed Pitafi ${ }^{\ddagger}$ \\ Syed Muhammad Javed Iqbal §
}

\begin{abstract}
The purpose of this research is to investigate different factors of employee's job motivation in the public sector commercial banks of Pakistan. Using a mixed method approach primary data were collected through survey questionnaires and interviews from 263 employees working in 4 large sized commercial banks of Pakistan. Findings reveal that perceived compensation fairness and job design are positively associated with the job motivation of bank employees. Moreover, the working environment plays a significant mediating role in the relationships between (i) compensation fairness and job motivation, and (ii) job design and job motivation. The statements derived from the interviews of employees working in the public sector commercial banks have further validated our results. The study also discusses the Policy guidelines, theoretical and practical implications, and limitations. As such, important implications have been accentuated for the top management and policy makers of the public sector commercial banks to ponder over the issues raised in the study.
\end{abstract}

Keywords: Perceived compensation fairness; job designs; working environment; employee's job motivation; public sector commercial banks.

\section{Introduction}

Motivation is defined as "willingness to exert a high level of inspiration to reach organizational goals, conditioned by the effort's ability to satisfy some individual need". Motivation is a psychological procedure that begins action in a task and establishes the form, duration, and intensity of engagement in that task (Acar, 2018). Specifically, motivation is the characteristics which keeps the individuals attach to their job, and so their interests lead them to uniquesness and innovation. Severl organizational leaders today realize that motivation enables employees to perform better taks at work for the long-term (Wong \& Ladkin, 2008).

\footnotetext{
*Department of Management Sciences, the Islamia University of Bahawalpur, Pakistan.

Email: emranrsheed@hotmail.com

$\dagger^{\dagger}$ Department of Management Sciences, the Islamia University of Bahawalpur, Pakistan. Email: wardanaj@hotmail.com

${ }^{\ddagger}$ School of Information and Management, Hefei University of Technology of China.

Email: hameedpitafi@hotmail.com

$\S$ Department of Management Sciences, the Islamia University of Bahawalpur, Pakistan.

Email: javed.iqbal@iub.edu.pk
} 
Almost all the HRM practices have a fundamental aim of acquiring a high level of work motivation that includes job involvement of individuals at work. Prior studies related to employee motivation also recommend a further research on factors affecting individual motivation at both public and private organizations. Soud (2014) suggests that more research should be conducted on factors that influence individual performance and those factors which motivate employees for high performance. Therefore, the current research invsitigates the influential factors contributing to employees motivation.

Rasheed, Humayon, Awan, et al. (2016) are of the view that organizational efficiency suffers from employees who have less motivation at work. Moreover, organizations invest ineffectual strategies to attain a motivated workforce to compete in the market. For example, unlike the common assumption, salary alone does not prove to be a vital motivating factor for everyone in an organization and the banks are no exception in this regard.

In essence, banking sector is important for the economy of Pakistan as it contributes significantly to the growth and development of the country. And it has enormous potential to contribute further to the development of the country. There are mainly two kinds of banks operated within the banking sector of Pakistan, public sector banks and private sector banks. In view of the competitive environment of the present times, public sector banks are struggling hard to retain their motivated and competitive workforce due to lacking several factors, such as competitive compensation packages and employee growth opportunities (Rashid \& Rashid, 2012). Public sector banks are, therefore, focusing on the development of their employees. Yet, it is quite a challenging task to understand what keeps the workforce motivated.

In this paper, we have explored several motivational factors that are influential to the employees working in the public sector banks. We mainly addressed the questions, (i) whether perceived compensation fairness and job design are associated with employee's job motivation, and (ii) how and why perceived compensation fairness and job design are associated with employee's job motivation in the banking organizations. By suggesting and testing this theoretical model of employee's job motivation in the public sector commercial banks of Pakistan, our study makes a number of contributions to the existing literature. For example, we have established a link between perceived compensation fairness and employee's job motivation, and job design and job motivation. Recently, scholars have emphasized the importance of exploring employee's job motivation in the banking sector (Aunjum, Abbas, \& Sajid, 2017; Gheitani, Imani, Seyyedamiri, \& Foroudi, 2019). As such, Aunjum et al. (2017) discussed that employee motivation is a critical element that plays an important role in organizational success; therefore, it is a worth investigating topic in the banking sector. Similarly, they further emphasized and suggested that investigating the antecedents of employee motivation in the banking sector is of an immense worth. Accordingly, we not only explored the job design and compensation fairness as the factors that influence employee's job motivation in the banking sector, but also we investigated the mediating role of the working environment (e.g., as a mediating mechanism) in the above stated relationships. In this regard, various studies have emphasized the importance of creative, challenging, and positive working environment for the employees to work effectively, and to remain motivated in organizations (Chatterjee, 2017; Narasuci, Setiawan, \& Noermijati, 2018; Saeed \& Nasir, 2016). Exploring work environment as a mediating 
mechanism in the relationships between employee motivation and its antecedents is a substantial contribution of this study. This is because it answers the questions of how and why the job design and compensation fairness affect employee's job motivation in organizations which is a narrowly researched area. Therefore, our study adds to the literature, especially in the field of Organizational Behavior, by emphasizing upon the role of compensation fairness and job design on important employee outcomes, such as job motivation. Moreover, by empirically investigating this model of employee motivation in the banking sector of Pakistan, we add to the literature on this particular sector. Hence, our study will help the policymakers, top management, and government authorities to look into these critical issues regarding employee's job motivation in the public sector commercial banks of Pakistan. Figure 1 explans the model of our study.

Figure 1

Conceptual Model

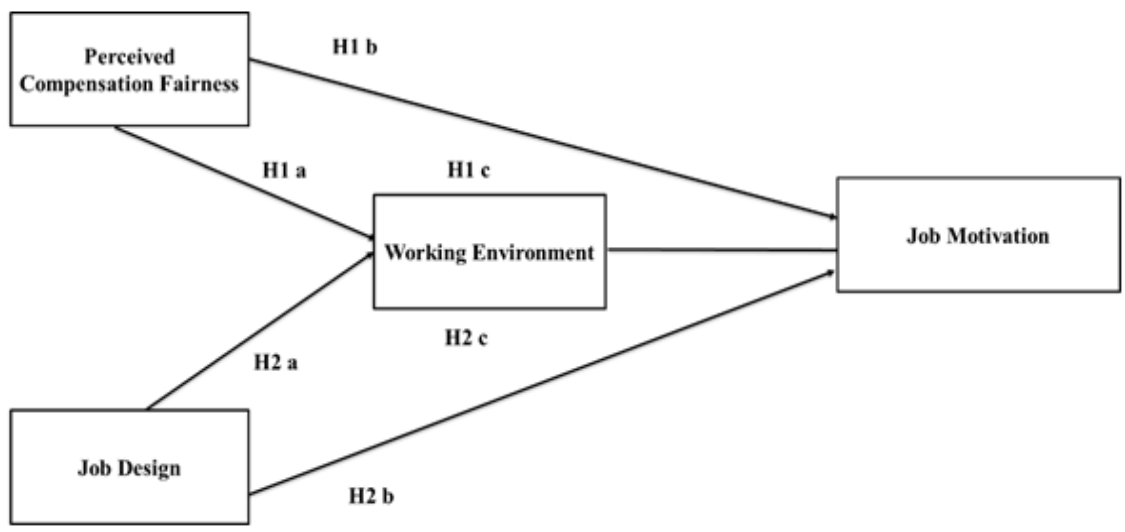

\section{Theory and Hypotheses Development}

\section{Perceived Compensation Fairness and Job Motivation}

Motivaiton theories (e.g., Maslow's hierarchy of need theory, Herzberg's motivation-hygiene theory, and Adam's Equity theory) help us to understand job motivation of employees in organizations (Rasheed et al., 2016). These theories provide a fundamental basis that helps us to understand the job motivation of employees. Maslow's need-based theory describes that there are five important needs of an individual which include "physiological need, security need, affiliation need, esteem need, and need of self-actualization". This theory can be applied to understand factors affecting job motivation of bankers; for example, bankers' physiological needs may include salary, health facility, home, transportation, and a comfortable working environment. The security needs of the banking employees may be related to their job security in the banks. Banking employees' affiliation needs may be comprised of the quality of the interpersonal relationships which they have with their 
coworkers and supervisor. Similarly, the esteem needs of the banking employees may include their desire for recognition at work from their supervisor and coworkers.

On the other hand, Adams theory of motivation considers that job motivation is the consequence of fair balance in the inputs and outputs of an employee (Pritchard, 1969). Thus, this theory helps us to understand about job motivation of banking sector employees in terms of their inputs and outputs at jobs. The notion of precieved fairness of employees should be considered in this regard. Perceived fairness is "refered to any element of the environment perceived by individuals or collectives as fair according to previous norms or standards". For example, the inputs that a banking employee is expected to deliver may include utilizing his or her skills and providing high quality customer services, and the outputs he or she expects from the organization are salary, recognition, empowerment, and appreciation. The balance between both the inputs which are expected by the banking organization and the outputs which are expected by the banking employee is important to be realized as any imbalance between these two, particularly due to perceived unfairness of employees, may create dissatisfaction among employees.

According to Reeve (2014), employee motivation is of two types, (a) internal motivation and (b) external motivation. Internal motivation actually arises from the nature of work itself, tasks and assignments, job description, and the working environment. The motivation that comes from the pay packages, financial benefits and other facilities obtained at the job is referred to as external motivation. Although money may be the biggest motivator for all employees, it is not necessary that money alone affects job motivation of all employees. There are intangible things, such as workers' inspiration to perform effectively, which motivate them to do their jobs in the best manner (Lange, Wartosch, Jentsch, \& Fuhrmann, 2006). Researchers have observed motivation as the common facet between employee retention and high performance (Sattar, Rasheed, Khan, Tariq, \& Iqbal, 2017). In addition, prevous research on employees' job motivation have explored several issues regarding job motivation of employees as important factors that affect their job efficiency in organziations. For example, Lee et al. (2017) found that low salary is the major issue that compels an employee to leave his job. Similarly, researchers have suggested that compensation is an important factor in causing employees motivation (Mabaso \& Dlamini, 2017; Rasheed et al., 2016). Mabaso and Dlamini (2017) discussed that fair compensation decisions are important for organizations not only to retain employees, but also to keep them motivated to perform their work duties. Hence, they firmly believed that reward system fairness is closely linked with employee motivation in organizations. Likewise, Gelard and Rezaei (2016) believed that justice regarding compensation of employees in organizations is critically important as the employees, who feel that they are financially discriminated, experience low job satisfaction and low job motivation. These research insights led us to assume a positive relationsbhip between perceived compensation fairness and employee's job motivation in the banking sector of Pakistan. Therefore, we hypothesized that;

$H_{1}$ : Perceived compensation fairness is positively associated with job motivation. 


\section{Job Design and Job Motivation}

According to Halepota (2005) motivation is an individual's active contribution and dedication to accomplish the proposed results. This suggests that employee motivation is an important factor for organizations to work well. Without motivation employees cannot offer their best, resulting in ineffective performance by them.

Parker, Morgeson, and Johns (2017) asserted that job designs have become a focus of research in organziations. They believe that well-designed jobs help in attaining the interests of employees as they feel boredom when jobs are poorly designed. Similarly, Parker et al. (2017) pointed out that job design and working environment are important factors in motivating workers. In contrast, an unclear job description, stressful working environment, and irrelevant administrative assignments can create overburden upon employees and lead them to be dissatisfied and demotivated from their jobs. Job design refers to the contents and methods of the job that an employee undertakes. For example, the job and roles they performs in the organization (Holman, Clegg, \& Waterson, 2002). Job design also reflects the processes and results of how job is designed, planned, experienced, and enacted. Specifically, the way that job is organized and prepared defines a number of job characteristics as experienced by the individual, which, in turn, increase the personal and organizational performance. Ho and Wu (2019) argued that job design can make employees perceive their contents of the jobs as meaningful which enhances their motivation to benefit the organizations. With regard to the perception that jobs can be prepared to increase the motivation and satisfaction of employees, a set of job features are proposed to explain the objectives behind the structure of tasks assigned to the individuals. These studies helped us to assume a positive association between job design and employee's job motivation. Accordingly, we developed the following hypothesis;

\section{$H_{2}$ : Job design is positively associated with employee's job motivation.}

\section{Mediating Role of Working Environment}

Working environment is described as the conditions in the surrounding of an employee in which he or she works. The working environment is comprised of several things, such as physical conditions, office equipments, office climate, and technology and tools. This also includes processes and procedures related to an employee's work. The working environment consists of several factors that include the physical setting and organisational features of the work itself which have been discussed by a number of scholars in different contexts (Awases, Gbary, Nyoni, \& Chatora, 2004). Specifically, Awases et al. (2004) stated that working environment together with compensation is one of the key motivators for employees. In the same way, Sugiharto (2017) suggested a positive association between compensation and working environment in the organizations. Other researchers, such as Umair (2016), also believed that compensation is an important factor in shaping a positive work environment in the organizations, especially when it is fair. In addition to compensation and compensation fairness, job design is another factor that positively infleuces the work environment of the organizations (Adil, 2017). Morgeson and Humphrey (2006) discussed that job designs are important in creating an effective working environment in 
the organizations. Fried et al. (2008) argued that the reason behind job designs gaining importance in today's literature is that job deisgns are positively associated with work environment.

Vermaak (2010) projected that the main reason for the shortage of skills is the lack of professional working environment where individual may grow better professional skills. Vermaak (2010) further anticipated that the better quality of working environment usually influence individuals' motivation. Probst, Baek, and Laditka (2010) stressed that a positive work environment, characterized by a positive management behavior, availability of sufficient time for tasks, employee being valued at the work and effective organziatioanl climate, is positively associated with employee motivaiotn and satisfaction at job. Jayaweera (2015) also maintained that work enviornemnt increases employee performance through job motivation in organizations. He explained that work environment is positively associated with employee's job motivation which is subsequently related to job performance. Similarly, Millette and Gagné (2008) arugued that good job designs help in creating positive work environment which can enhance workers' motivation at jobs. These past theoretical insights assisted us to consider that compensation fairness and job deisgns are positively associated with work environment, which, in turn, are related to employees' motivation in the banking sector organizations of Pakistan. We, therefore, hypothesized that;

\footnotetext{
$H_{3 a}$ : Perceived compensation fairness is positively associated with the working environment.
}

$H_{3 b}$ : Working environment mediates the relationship between perceived compensation fairness and job motivation.

$H_{4 a}$ : Job design is positively associated with the working environment.

$H_{4 b}$ : Working environment mediates the relationship between job design and job motivation.

\section{Methodology}

\section{Data Collection Procedures}

The primary data required for this study was collected through a survey conducted in the public sector commercial banks of Pakistan. The research instrument was designed, with 18 closed ended structured questions, on 5 points Likert scale, and 12 open-ended interview questions. 450 questionnaires were distributed through personal visits to the banks in January 2018. Out of the 450 questionnaires distributed, 327 questionnaires were received back in almost one and half months duration. This formulated the response rate of $72.67 \%$. Of the 327 filled questionnaires which were received back, 64 were excluded from the final analyses as they were partially filled; therefore, the final sample size used in the study was 263 . Of the 263 respondents, $53.7 \%$ were males, $68.7 \%$ were between the age group of 25 to 35 years, $64 \%$ were married, and $42.1 \%$ were a bachelor's degree holder. 


\section{Measures}

\section{Perceived Compensation Fairness}

The 3-item scale of perceived compensation fairness was taken from Nyberg (2010). This scale was designed on 5 points likert scale ranging from $1=$ strongly disagree to $5=$ strongly agree. A sample item from this scale includes, "the compensation plans of this organization reward outstanding job performance". The Cronbach's alpha for this scale in our study was 0.88 .

\section{Job Design}

The 3-item scale of job design was adapted from Morgeson and Humphrey (2006). This scale was designed on 5 points likert scale ranging from $1=$ strongly disagree to $5=$ strongly agree. A sample item from this scale is, "my job contains motivational characteristics of the job". The Cronbach's alpha for this scale in our study was 0.84 .

\section{Working Environment}

The 6-item scale of working environemnt was adapted from Tourangeau and McGilton (2004). This scale was designed on 5 points likert scale ranging from $1=$ strongly disagree to $5=$ strongly agree. Sample items from this scale include, "people who work in this environment have shared goals" and "people working in this environment feel valued for the work they do". The Cronbach's alpha for this scale in our study was 0.91.

\section{Motivation}

A 6-item scale of employee's job motivation was adapted from Venkatesh, Morris, Davis, and Davis (2003). This scale was designed on 5 points likert scale ranging from $1=$ strongly disagree to $5=$ strongly agree. Sample items from this scale include, "my job enables me to accomplish tasks more quickly" and "my job improves my job performance". The Cronbach's alpha for this scale in our study was 0.82 .

\section{Control Variables}

We also included age, gender, marital status, and education as the control variables in this study as previous studies have indicated relationships of these variables with the main variables of our study.

\section{Analysis and Results}

Our study deals with two types of data, that is quantitative data and qualitative data. We utilized SPSS PROCESS macros for analyzing the quantitative data to test our study hypotheses. Following the recommendations of Aiken et al. (1991), before analysis, we mean centered all the continuous measures. As for the dealing with the qualitative data, which were obtained in the form of open-ended statements from the respondents' responses 
to the interview questions, we employed content analysis. The respondents' statements reported for the purpose of the content analysis in this paper are the original statements of the respondents, captured during the interviews, with no changes made on them what so ever.

\section{Descriptive Statistics}

Table 1 reports mean, standard deviation, and inter-correlation among the constructs used in this study. Perceived compensation fairness $(\mathrm{r}=.42, \mathrm{p}=.01)$ and job design $(\mathrm{r}=$ $.51, \mathrm{p}=.01)$ are positively associated with working environment. Similarly, perceived compensation fairness $(\mathrm{r}=.39, \mathrm{p}=.01)$ and job design $(\mathrm{r}=.62, \mathrm{p}=.01)$ are positively associated with job motivation. In addition, working environment is positively associated with employee's job motivation $(\mathrm{r}=.49, \mathrm{p}=.01)$.

Table 1

Mean, Standard Deviations, and Inter-correlations

\begin{tabular}{|c|c|c|c|c|c|c|}
\hline Variables & Mean & S.D & 1 & 2 & 3 & 4 \\
\hline $\begin{array}{l}\text { 1. Perceived compensation } \\
\text { fairness }\end{array}$ & 3.870 & 0.790 & 0.880 & & & \\
\hline 2. Job design & 3.630 & 0.520 & $0.480^{* *}$ & 0.840 & & \\
\hline 3. Working environment & 3.830 & 0.810 & $0.420^{* *}$ & $0.510^{* *}$ & 0.910 & \\
\hline 4. Job motivation & 4.160 & 0.730 & $0.390^{* *}$ & $0.620^{* *}$ & $0.490^{* *}$ & 0.820 \\
\hline
\end{tabular}

\section{Common Method Variance}

As the data regarding our independent and dependent variables were collected from the single source at the same time, there may be chances of biasness in the data set. Scolars have suggested several procedures to deal with the problem of common method bias, such as Herman's single factor test. In this study, we dealt with the biasness problem using two different techniques as suggested by Podsakoff, MacKenzie, and Podsakoff (2012). In the first technique, the CLF method was applied on all the items of our variables. For this procedure, initially, we computed the regression weights of all the items. Next, the common factor was incorporated in the research model, and again we computed the regression weights of all the constructs. Finally, we compared the regression weights of both the analyses and did not find any dominating factor arsing from both the analyses. In the second technique, Herman's single factor approach was used for testing the common method variance (CMV). Results show that first factor only generated $27.2 \%$ value of the total varance which is less than $50 \%$. Therefore, the results obtaind from utilizing both techniques confirmed that there is no existence of biasness in the data set used for the study. Moreover, as we collected qualitative as well as quantitative data to assess the variables of the study by maintaining the confidentiality and annonimity of the respondents, this may also have resolved the CMV issue (Podsakoff, MacKenzie, Lee, \& Podsakoff, 2003). 


\section{Hypotheses Testing}

For testing our fully hypothesized research model, we utilized SPSS PROCESS macro Model 4. The results are reported in Table 2 and Table 3. These results are consistent with our preliminary analysis as perceived compensation fairness $(\mathrm{B}=.38, \mathrm{t}=2.92, \mathrm{p}=$ .01 , Table2) and job design $(\mathrm{B}=.21, \mathrm{t}=4.20, \mathrm{p}=.01$, Table 3$)$ have positive associations with job motivation which supports our $\mathrm{H} 1$ and $\mathrm{H} 2$. The results further show that perceived compensation fairness $(\mathrm{B}=1.62, \mathrm{t}=6.48, \mathrm{p}=.001$, Table 2$)$ and job design $(\mathrm{B}=.53$, $\mathrm{t}=10.60, \mathrm{p}=.001$, Table 3 ) have positive associations with working environment which supports our hypotheses H3a and H4a. Further, our results have shown that working environment is positively associated with job motivation $(\mathrm{B}=1.63, \mathrm{t}=7.76, \mathrm{p}=.001)$.

Table 2

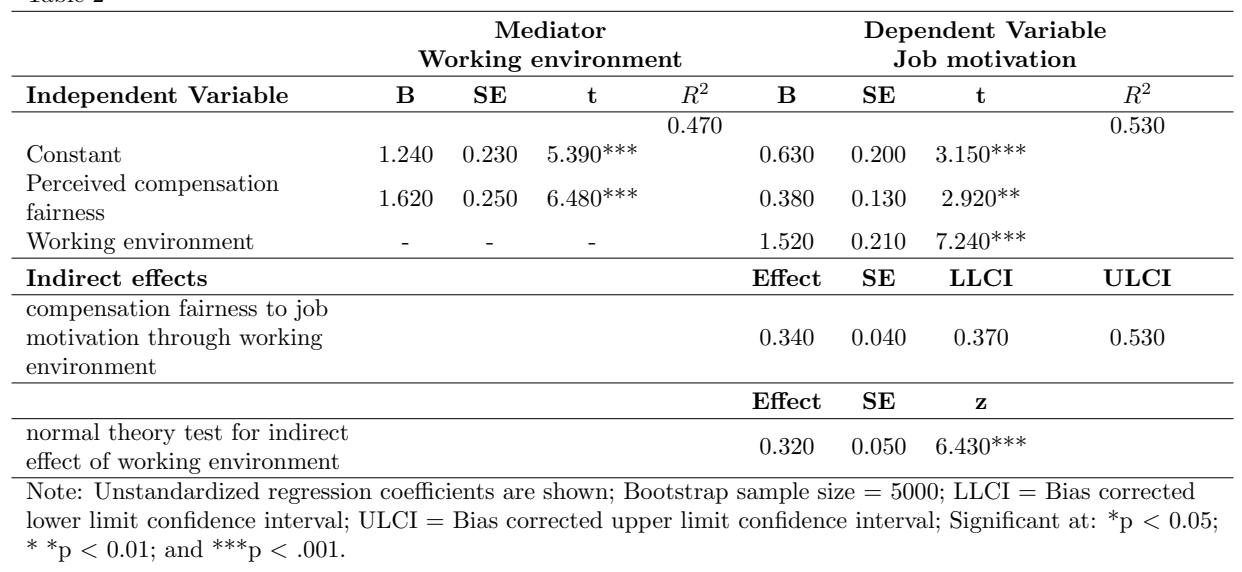

\section{Mediation Analysis}

For mediation analysis, we performed Sobel tests using the bootstrap procedure with $95 \%$ bias correlated confidence intervals (CIs). The indirect relationship between perceived compensation fairness and job motivation (Sobel $\mathrm{z}=6.43, \mathrm{p}<.001$, Table2), and job design and job motivation (Sobel $\mathrm{z}=10.34, \mathrm{p}<.001$, Table 3 ) are significant in both cases. In addition, bootstrap CIs do not contain zero (perceived compensation fairness is 0.37 to 0.53 , Table 2 ; job design is 0.31 to 0.42 , Table 3 ). These results provide evidence that the working environment is a significant mediator in the relationship between perceived compensation fairness and job motivation, and job design and job motivation. These results provide support to our hypotheses $\mathrm{H} 3 \mathrm{~b}$ and $\mathrm{H} 4 \mathrm{~b}$.

It is a worth noting point that people in the developing countries, such as Pakistan, are more concerned about their financial constraints. In view of this, a high salary or compensation benefits are encouraging factors, and so motivate employees in the public sector commercial banks to put their best efforts at work as they know that the better they will work, the better they will be able to earn. 
Table 3

\begin{tabular}{|c|c|c|c|c|c|c|c|c|}
\hline \multirow[b]{2}{*}{ Independent Variable } & \multicolumn{4}{|c|}{$\begin{array}{c}\text { Mediator } \\
\text { Working environment }\end{array}$} & \multicolumn{4}{|c|}{$\begin{array}{c}\text { Dependent Variable } \\
\text { Job motivation }\end{array}$} \\
\hline & B & SE & $\mathbf{T}$ & $R^{2}$ & B & SE & $\mathbf{t}$ & $R^{2}$ \\
\hline & & & & 0.290 & & & & 0.510 \\
\hline Constant & 1.510 & 0.200 & $7.550 * * *$ & & 1.750 & 0.180 & $9.720 * * *$ & \\
\hline Job design & 0.530 & 0.050 & $10.60^{* * *}$ & & 0.210 & 0.050 & $4.200^{* *}$ & \\
\hline Working environment & - & - & - & & 1.630 & 0.210 & $7.760^{* * *}$ & \\
\hline Indirect effects & & & & & Effect & SE & LLCI & ULCI \\
\hline \multirow[t]{2}{*}{$\begin{array}{l}\text { Job design to working environment } \\
\text { through job motivation }\end{array}$} & & & & & 0.320 & 0.050 & 0.310 & 0.420 \\
\hline & & & & & Effect & SE & $\mathbf{Z}$ & \\
\hline $\begin{array}{l}\text { normal theory test for indirect effect of } \\
\text { working environment }\end{array}$ & & & & & 0.310 & 0.030 & 10.34 & \\
\hline
\end{tabular}

\section{Qualitative Analysis}

During survey interview, an officer at a bank mentioned that;

"Bonuses and compensation schemes can prove to be an encouraging factor for the banking employees as we all need financial support. This is needed to be realized so that the employees put their best efforts in their profession."

Another senior banker pointed towards an important situation and opined that;

"Due to competition in the banking industry, employees are switching their jobs from public sector banks to private sector banks because private banks are offering very high salary packages."

A branch manager in a public sector bank discussed another view of job switching and compensation issue in the banks. He said that;

"To increase their businesses, public sector banks, these days, are hiring staff who have experience of working in the private banks. When an employee switches his or her job from a private bank to a public sector bank, he or she gets almost 50 to 100 percent raise in his or her pay package. This actually demotivates current employees of the public sector banks who have more experience than the newcomers. If banks just offer 20 to $30 \%$ rise in the salaries of their current staff rather than offering 50 to 100 percent rise to the newcomers, the current employees may feel much valuable than the new ones."

These responses show that employees in the public sector banks are not much satisfied with perceived compensation fairness and so the job switch rate is much higher in the public sector banks of Pakistan as compared to the private banks. An interesting factor discovered through the interview survey is that despite their low salaries, bankers spend a portion of their salaries on maintaining their dressing aesthetics in order to carry themselves well in the corporate world as a fulfillment of their job requirement. What's more interesting is that 
these expenses are not merely limited to maintaining a proper dress code at the workplace, but banking employees face the pressure of owning vehicles and beautiful houses as they are largely considered to be one of the well off communities in the country. The reason behind this general consideration is that in the older days, banking was a profession where staff packages were higher than the other professions. Still today, due to organizational culture and the nature of their job, bankers need to maintain a moderate level of social status. Hence, they maintain their smart dressing, vehicles and beautiful houses by availing staff loans or advance salaries which consequently decreases their disposable income and lowers their motivation at the job.

An officer from a public sector commercial bank indicated this situation in these words;

"In Pakistan, bankers are most stressed and depressed, but still well-dressed, people."

Another senior banker maintained that;

"Banking was the most attractive profession due to several factors in the past, such as the availability of the heavy amount of interest free staff loan... But now interest rate on staff finance have also been increased. If we avail loans to maintain our social status, a huge portion of our salaries goes into the loan settlement which actually decreases our take-home salaries...We are asked to come well dressed...And perhaps bankers are the only community in Pakistan who wear new neckties everyday...Our job responsibilities require a personal vehicle too...How can we maintain this status without smart pay packages and organizational support?"

Our survey notified that the major hurdles in the job design of the banks are the amount of workload and the long working hours. Bankers have strongly expressed that current 09:00 am to 05:00 pm non-stop banking with a huge workload at the time of closing is causing stress among the banking professionals. 09:00 am to 05:00 pm non-stop banking services for the customers combined with the closing anxiety at 05:00 pm, and audit pressure and rectification activities create an excessive workload on the banking employees which makes a very long working day for them at the office.

Accordingly, one of the respondents asserted his opinion as;

"Banks should be opened from 09:00 am to 03:00 pm for customer handling...By doing so, they will have 02 hours for closing the activities, and staff will be able to go back to their homes around 05 O' clock in the evening...Top management of the banks should realize the importance of work-life balance which is necessary for every human being in this stressed and tensed environment."

Interviewees have also reported that currently many of the public sector commercial banks have refurbished branch offices. Hence, they have been provided with the essential office and work necessities, such as separate workstation with the latest computer systems, 
printers, scanners, etc. However, employees demand the availability of high-speed internet services with no restrictions on surfing the social media websites, during the working hours, so that they remain updated and connected with the rest of the world.

Moreover, it is found through the interview statements of the employees of the public sector commercial banks of Pakistan that they are not happy with their performance management system and allocation of targets which subsequently affects their promotions and other career advancement aims. For example, one of the bank employees said that;

"What is the benefit of a complicated performance appraisal form when you only need to make your boss happy in every aspect?...I should be given promotion and other rewards if I am objectively giving more business to the bank...If the figures are showing my performance higher than the recommendation of my current supervisor then who is at fault?... What should be given more importance?"

As previously mentioned, it was also noted in the interview survey that employees are not happy with the goals and targets assigned to them by the top management. In fact most of the bankers were of the view that mostly the targets assigned to them in their organizations are largely unachievable;

With regard to this, one of the officers at the bank pointed out that;

"Top management usually knows that the annual targets and goals they have assigned to the banking officers are unrealistic and unachievable, but still they assign them with such targets as they hope for the partial achievements of them. Top management in the banking sector should realize the importance of SMART (specific, measurable, achievable, realistic, and time-bound) goals. They should know that a realistic goal has more tendency to be achieved than an unrealistic one."

Similarly, another officer stated that;

"The matter of unrealistic goals at the banking sector can be compared with the Pakistan cricket team when it is given unrealistic targets to meet... When it is given a target of 350 or 380 runs to achieve, the whole team gets the pressure of the huge total and goes back to the pavilion on 200 or 220 runs...But when the target to be achieved is between 250 to 270 runs, the team easily achieves it."

\section{Discussion, Implications, and Limitations}

\section{Discussion}

This study was conducted in order to understand the job motivation factors for the employees working in the public sector commercial banks of Pakistan. A comprehensive model 
has been developed by us to describe the relationships between employee's perceived compensation fairness, job design, working environment, and job motivation. The empirical results of our study have confirmed the hypothesized relationships; for example, perceived compensation fairness is found to be positively associated with organizational working environment and employee's job motivation in the public sector commercial banks of Pakistan. Results of the study also confirm that job design is positively associated with organizational working environment and employee's job motivation in the public sector commercial banks of Pakistan. As for the mediation results of our study, they show that the working environment plays a significant mediating role in the relationships between (i) perceived compensation fairness and job motivation, and (ii) job design and job motivation. Hence, this is a distinctive study conducted on the public sector commercial banks to understand the factors that affect employee's job motivation. Our findings call researchers and policymakers' attention towards the issues, such as perceived job fairness and contemporary job design, which have the ability to motivate employees in the organizations. Similarly, our findings regarding the positive impact of perceived compensation fairness and job design on employee's job motivation are consistent with the previous research; for example, (Kuvaas, 2006; Morgeson \& Humphrey, 2006; Witt \& Nye, 1992) also supported these results in their studies.

Similarly, the investigation of the working environment as a mediating variable in our model is an inimitable finding which contributes to the literature in understanding the reason that why perceived compensation fairness and job design are related to employee's job motivation in the public sector commercial banks. This finding has confirmed the previous studies; for example, (Lopez, 2017) also discovered a positive impact of working environment on employee's outcomes. Thus, our research findings have enriched the literature by investigating the important role of factors, such as job design, perceived compensation fairness and work environment on employee's job motivation.

Moreover, our study has important practical implications for individuals, managers, organizations, human resource practitioners and policymakers with regard to employee's job motivation. As discussed earlier employee's job motivation is an organizationally valuable outcome that all organizations need at all times not only to remain competitive, but also to achieve their important goals and objectives. Therefore, policymakers of the public sector commercial banks and the human resource managers are needed to find out the ways to enhance employee perceptions about the fairness of compensation packages and for making job designs more enriched. And as found in the study, these two factors contribute significantly to the job motivation of employees. This implies that the public sector banks should, therefore, look into several ways which can enrich employee's job design aimed at enhancing employee's motivation. For example, policies such as job rotation, job enrichment, and flexible working hours may be introduced in the banks to attain employees' job motivation. Policy makers and government authorities, including the regulatory bodies, may also compel the top management of the public sector banks to provide training workshops designed to enrich the working environment in the banks. Similarly, vocational psychologists and human resource practitioners in the public sector organizations should provide due importance to employees' perceptions about the fairness of compensation policies. 


\section{Implications}

The current study has several theoretical and practicle implications. First, the study provides guidance to the managers so that they understand thoroughly the realities behind employee's motivations. When managers are able to understand the subtleties of employees' motivation, they will design ideal jobs, with right features, for them. These ideas are consistent with the past suggestions (Breaugh, 2012). Muslim et al. (2016) argued that motivation helps the employees feel a sense of belonging to the organization, which, in turn, benefits the organization with its achievement of the long-term results through the efficiency and effectiveness of its employees.

Second, we suggest that managers should care about each employees' differences by using several approaches, especially by taking into attention that motivation is one of the basic components that influences individual's performance. Individuals generally feel motivated when they are included in making efficient strategic contributions towards the achievement of organizational objectives.

Finally, our study's results also suggest that managers should implement friendly working environment and design jobs' contents in such a way that it motivates the employees towards work. The idea behind this is that highly motivated employees are productive and perform well as compared to the less motivated employees. Hence, overall, the study essentially provides suggestions and guidance to the bank managers with regard to employees' job motivation.

\section{Limitations and Directions for Future Research}

Although we conducted a mixed method research study with comprehensive data of qualitative and quantitative nature, nevertheless, our study has some limitations. Firstly, the sample belongs to one country that reduces the generalizability of the research findings. We, therefore, recommend the future researchers to investigate our model in other countries and cultures. Secondly, our data is cross-sectional in nature which may be subject to causing CMV; however, we have taken procedural remedies to reduce the chances of CMV. Future studies may validate our findings through a longitudinal or experimental study design. In addition, although the aim of this research was to identify the specific factors that influence the motivation of the public sector banking employees, the survey highlighted many other variables which may be explored in the future studies including but not limited to job stress and satisfaction. Similarly, it will be important to develop a boundary condition in the relationships we have identified. For example, perceived career opportunities may serve as a moderator at the first and second stage of our model.

\section{Conclusion}

Our study investigated the role of perceived compensation fairness, job design, working environment, and employee motivation in the public sector commercial banks of Pakistan. Findings showed the significant positive relationships of the variables such as compensation fairness, job designs, and working environment with the public sector employee's motivation 
in commercial banks of Pakistan. It is suggested that not only a higher salary, but also a combination of several factors, such as systematically designed jobs and work environment, cause the motivation among the employees in the public sector commercial banks. Hence, there is a need that top management of the banks, regulatory bodies, Government officials, and policymakers should carefully look into the factors explored in our study for achieving a highly motivated workforce in the public sector commercial banks of Pakistan. 


\section{References}

Adil, M. (2017). Impact of job design on employees psychological work reactions: Empirical evidence from the universities of Khyber Pakhtunkhwa. Journal of Managerial Sciences, 11.

Aunjum, A. H., Abbas, G., \& Sajid, M. (2017). Transformational leadership and employee motivation in banking sector of Pakistan. Advances in Economics and Business, $5(9), 487-494$.

Awases, M., Gbary, A., Nyoni, J., \& Chatora, R. (2004). Migration of health professionals in six countries: a synthesis report. World Health Organization, 65, 38-42.

Breaugh, J. A. (2012). Employee recruitment: Current knowledge and suggestions for future research. The Oxford Handbook of Personnel Assessment and Selection, 6887.

Chatterjee, P. (2017). Job satisfaction, occupational stress and work motivation: A comparative analysis among the banking and academic sector professionals. IOSR Journal of Business and Management, 19(3), 30-43.

Gelard, P., \& Rezaei, S. (2016). The relationship between job motivation, compensation satisfaction and job satisfaction in employees of tax administration-a case study in Tehran. Asian Social Science, 12(2), 165-171.

Gheitani, A., Imani, S., Seyyedamiri, N., \& Foroudi, P. (2019). Mediating effect of intrinsic motivation on the relationship between islamic work ethic, job satisfaction, and organizational commitment in banking sector. International Journal of Islamic and Middle Eastern Finance and Management.

Halepota, H. A. (2005). Motivational theories and their application in construction. Cost Engineering, $47(3), 14$.

Ho, C.-W., \& Wu, C.-C. (2019). Using job design to motivate employees to improve highquality service in the airline industry. Journal of Air Transport Management, 77, $17-23$.

Holman, D., Clegg, C., \& Waterson, P. (2002). Navigating the territory of job design. Applied Ergonomics, 33(3), 197-205.

Jayaweera, T. (2015). Impact of work environmental factors on job performance, mediating role of work motivation: A study of hotel sector in England. International Journal of Business and Management, 10(3), 271.

Kuvaas, B. (2006). Work performance, affective commitment, and work motivation: The roles of pay administration and pay level. Journal of Organizational Behavior: The International Journal of Industrial, Occupational and Organizational Psychology and Behavior, 27(3), 365-385.

Lange, P. F., Wartosch, L., Jentsch, T. J., \& Fuhrmann, J. C. (2006). ClC-7 requires ostm1 as a $\beta$-subunit to support bone resorption and lysosomal function. Nature, 440(7081), 220-223.

Lee, C.-C., Lee, C.-W., Jiang, L.-T., Lin, C.-Y., Huang, F.-L., Yu, C., et al. (2017). The impact of salary structure, performance requirements, and type of business on the performance of housing brokerage employees. Asian Economic and Financial Review, $7(7), 685-699$. 
Lopez, T. H. (2017). A model of job satisfaction: The impact of work value orientation on millennials in professional selling careers (Unpublished doctoral dissertation). Northcentral University.

Mabaso, C. M., \& Dlamini, B. I. (2017). Impact of compensation and benefits on job satisfaction. Research Journal of Business Management, 11(2), 80-90.

Millette, V., \& Gagné, M. (2008). Designing volunteers' tasks to maximize motivation, satisfaction and performance: The impact of job characteristics on volunteer engagement. Motivation and Emotion, 32(1), 11-22.

Morgeson, F. P., \& Humphrey, S. E. (2006). The work design questionnaire (WDQ): developing and validating a comprehensive measure for assessing job design and the nature of work. Journal of Applied Psychology, 91(6), 1321.

Narasuci, W., Setiawan, M., \& Noermijati, N. (2018). Effect of work environment on lecturer performance mediated by work motivation and job satisfaction. Jurnal Aplikasi Manajemen, 16(4), 645-653.

Nyberg, A. (2010). Retaining your high performers: Moderators of the performance-job satisfaction-voluntary turnover relationship. Journal of Applied Psychology, 95(3), 440.

Parker, S. K., Morgeson, F. P., \& Johns, G. (2017). One hundred years of work design research: Looking back and looking forward. Journal of Applied Psychology, 102(3), 403.

Podsakoff, P. M., MacKenzie, S. B., Lee, J.-Y., \& Podsakoff, N. P. (2003). Common method biases in behavioral research: a critical review of the literature and recommended remedies. Journal of applied psychology, 88(5), 879.

Podsakoff, P. M., MacKenzie, S. B., \& Podsakoff, N. P. (2012). Sources of method bias in social science research and recommendations on how to control it. Annual Review of Psychology, 63, 539-569.

Pritchard, R. D. (1969). Equity theory: A review and critique. Organizational Behavior and Human Performance, 4(2), 176-211.

Probst, J. C., Baek, J.-D., \& Laditka, S. B. (2010). The relationship between workplace environment and job satisfaction among nursing assistants: Findings from a national survey. Journal of the American Medical Directors Association, 11(4), 246-252.

Rasheed, M. I., Humayon, A. A., Awan, U., et al. (2016). Factors affecting teachers' motivation. International Journal of Educational Management.

Rashid, S., \& Rashid, U. (2012). Work motivation differences between public and private sector. American International Journal of Social Science, 1(2), 24-33.

Reeve, J. (2014). Understanding motivation and emotion. John Wiley \& Sons.

Saeed, H. M. I., \& Nasir, N. (2016). Work environment on job satisfaction with mediating effect of motivation among school teachers in Lahore, Pakistan. Journal of Management Engineering and Information Technology, 3(6).

Sattar, M. A., Rasheed, M. I., Khan, I. U., Tariq, H., \& Iqbal, J. (2017). Why adaptable individuals perform better: The role of orientation to happiness. Australian Journal of Career Development, $26(3), 134-141$.

Sugiharto, T. (2017). Effect of compensation and working environment motivation and job satisfaction in order to increase employee performance at the department of co- 
operative micro small medium enterprises (SMEs) and industry in Ngawi. eAbstract Excellent, 3(1).

Tourangeau, A. E., \& McGilton, K. (2004). Measuring leadership practices of nurses using the leadership practices inventory. Nursing Research, 53(3), 182-189.

Umair, T. (2016). Impact of salary structure, employee perception and working conditions on the organizational commitment in SME. European Journal of Business and Management, 8(7), 64-72.

Venkatesh, V., Morris, M. G., Davis, G. B., \& Davis, F. D. (2003). User acceptance of information technology: Toward a unified view. MIS Quarterly, 425-478.

Vermaak, A. (2010). Strategic approach to skills development and staff retention. In Port Elizabeth: Nelson Mandela Bay Municipality, 62nd AMEU Convention.

Witt, L. A., \& Nye, L. G. (1992). Gender and the relationship between perceived fairness of pay or promotion and job satisfaction. Journal of Applied Psychology, 77(6), 910.

Wong, S. C.-k., \& Ladkin, A. (2008). Exploring the relationship between employee creativity and job-related motivators in the Hong Kong hotel industry. International Journal of Hospitality Management, 27(3), 426-437. 